\title{
On the Structure and Development of the Secretory Tissues of the Marattiaceae.
}

\author{
BY \\ CYRIL WEST, B.SC., F.L.S. \\ With Plate XVIII and fourteen Figures in the Text.
}

THE Marattiaceae are characterized by the possession of secretory 1 tissues of two kinds, which have been called mucilage-canals, and also cells or ducts containing tannin. Owing to their prominence in this group of Ferns these tissues have received the attention of many botanists, the first reference to them appearing as early as 1847, when Karsten (11) observed mucilage-canals in the stem, leaves, and roots of the Marattiaceae and suggested that the cells bordering on these canals took part in the secretion of the mucilage.

Harting (7) distinguished between the ramifying canals with a definite epithelium of small cells and the simple intercellular canals which he observed in a doubtful species of Angiopteris.

Two kinds of mucilage-canal were also described and figured by Frank (10), who contrasts those which occur in the outer thick-walled tissue of the petiole of Angiopteris with those which are found in the inner thin-walled tissue. To the former he ascribes a lysigenous origin, but to the latter, which are wide-lumened and are lined with an epithelium of small iso-diametric cells, he attributes a schizogenous origin.

As a result of his investigations on species of Angiopteris and of Marattia, Trécul (21) arrived at a very similar conclusion, but maintains that the secretory elements in the fibrous zone of the petiole consist of a series of superposed large elongated cells containing tannin, while the true mucilage-ducts, although they arise schizogenously, possess only a transitory epithelium.

Van Tieghem (20) found both mucilage-ducts and tannin-sacs in the root and petiole of Marattia laevis. According to this author the former (mucilage-ducts) are lined with an indefinite epithelium of small irregular cells, from which the mucilage is derived. He adds, however, that here and there the ordinary large cells of the cortex abut directly upon the canal. In the root of Angiopteris evecta no mucilage-canals were found.

[Annals of Botany, Vol. XXIX. No. CXV. July, 1915.] 
Russow (18) accepted Frank's explanation of the development of two kinds of canal, which arise by a schizogenous and a lysigenous process respectively.

In the course of his investigations on the anatomy of the Marattiaceae, Kühn (13) gave an account of the lysigenous development of the mucilagecanals in the roots of Angiopteris, Marattia, and Kaulfussia.

But the first comparative account of the development of the mucilagecanals of the Marattiaceae was published by Brebner (2), who arrived at the conclusion that they are schizogenous intercellular spaces, which develop much in the same way as the well-known resin-canals of Pimus, Hedera, \&c. A well-defined living secretory epithelium is generally developed around these intercellular spaces. In a more recent communication (3) this author still maintains this view.

Lutz (14) published a full account of the development of the mucilagecanals in Angiopteris evecta and in Marattia fraxinea, var., and attempted to reconcile the conflicting statements of the earlier investigators. This botanist distinguished between the typical mucilage-canals, which develop schizogenously, and a second type of mucilage-canal, which arises by the solution of the terminal parting-walls of rows of tannin-cells. The tanniniferous contents of the latter are said to be gradually replaced by true mucilage. ${ }^{1}$

Farmer and Hill (9), on the other hand, ascribed a lysigenous development to the mucilage-canals which occur in the young sporophyte of Angiopteris evecta.

In his well-known memoir on the Psaronieae and Marattiaceae Rudolph (17) alludes to and figures (1.c., p. 196, Taf. iii, Fig. 2a) both types of secretory tissue described by Lutz.

Campbell (4) observed lysigenous mucilage-canals in the stem of Danaea elliptica and of Danaea Fenmani, but states (1.c., p. I8I) with reference to Kaulfussia that the lysigenous origin of the canals is less evident than in Danaea, while it is not impossible that they may sometimes be of schizogenous origin.

Charles (6) concluded that the mucilage-ducts in Marattia alata originate both schizogenously and lysigenously, generally the former.

In view of the striking lack of agreement in existing accounts of the structure and development of the secretory tissues of the Marattiaceae, which suggests variation or vagueness in these structures, a reinvestigation of this point seemed desirable, since it might throw some light on the muchdebated subject of the phylogeny and affinities of this group of Ferns (cf. Matte, 15, p. 206 ; Seward, 19, p. 2I7), including the interrelationships of the constituent genera.

With this end in view the present investigation was undertaken.

1 The results obtained by Lutz were adopted by Bitter (1) in his account of the Marattiaceae in Engler and Prantl, Die natïrlichen Pflanzenfamilien. 


\section{MATERIAL AND METHODS.}

Material of the following genera and species was examined :

Angiopteris evecta, Hoffm. Archangiopteris Henryi, Chr. et Gies.

Danaea alata, Sm.

Danaea nodosa, Sm.

Danaea simplicifolia, Rudge.
Kaulfussia aesculifolia, Bl. Marattia alata, Sw. Marattia attenuata, Lab. Marattia Cooperi, Mre. Marattia fraxinea, Sm.

In order to eliminate at least one possible source of error, part of this material was carefully fixed in chromo-acetic or in acetic alcohol (glacial acetic acid, I part : absolute alcohol, 3 parts). The remainder was fixed in 70 per cent. alcohol.

For this investigation serial sections were necessary, therefore microtomed sections were cut $(6 \mu-\mathrm{I} 2 \mu)$, but care was taken to check the work by examining thick hand-sections.

Various stains and reagents were employed, including safranin, gentianviolet, eosin, methylene blue, iodine, ferric chloride, Congo red, and haematoxylin. ${ }^{1}$ These were used singly and in combination.

\section{Development and Structure of the Mucilage-canals. ${ }^{2}$}

\section{Method i. Protogenetic Lysigenous ${ }^{3}$ Mucilage-canals.}

The mucilage-canals of the Marattiaceae usually arise on the first differentiation of tissues at the growing-point of the stem or root. In the leaf also the very early differentiation of the canal-initials was observed.

Both transverse and longitudinal sections through the young tissues of the stem, root, or leaf of by far the largest number of genera and species examined reveal scattered groups of cells, the canal-initials, which remain meristematic after the neighbouring cells of the ground-tissue have passed over into the permanent condition. These specialized cells usually divide into 2, 4, or 6 without any appreciable increase in size; as a result of this cell-division groups of cells, which can readily be distinguished from the surrounding cells not only by their smaller size but also by their relatively larger nuclei and denser cytoplasm, are produced (Text-figs. I-4 ; Plate XVIII, Figs. 6 and I2).

1 This reagent was made up according to the formula published by Kleinenberg in Quart. Journ. Micr. Sci., lxxiv, 1879 , p. 208.

2 In this paper the term 'mucilage' is applied to a substance (or substances) of unknown chemical composition, which exhibits certain recognized physical properties. For an account of the optical properties of various plant mucilages, including that of Angiopteris, see Schwendener, S., 'Nochmals über die optisch-anomale Reaction des Traganth- und Kirschgummis,' in Sitzungsb. d. Akad. d. Wiss. zu Berlin, Bd. ii, I890, p. I I 3 I.

${ }^{3}$ Frank, 1. c. 


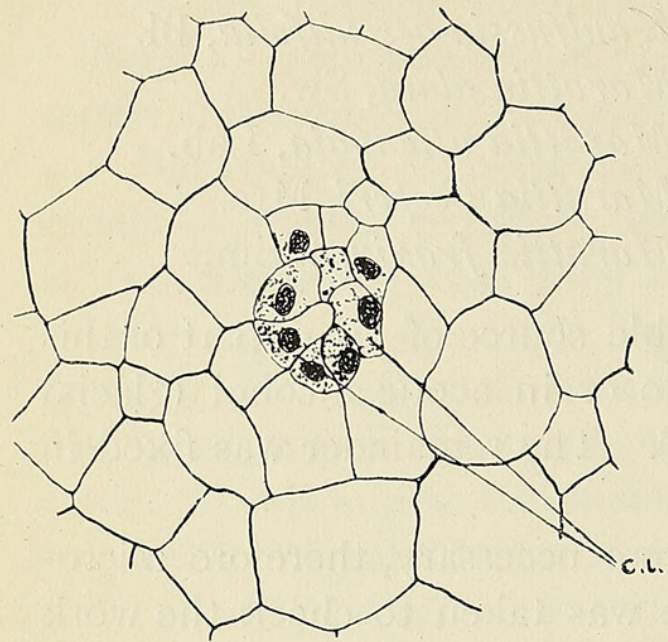

Text-FIG. I. Early stage in development of mucilage-canal in the stem of Angiopteris evecta, Hoffm. $\times 350 . \quad c . i$. $=$ canal initials The shaded areas represent protoplasm in process of mucilaginous degeneration.

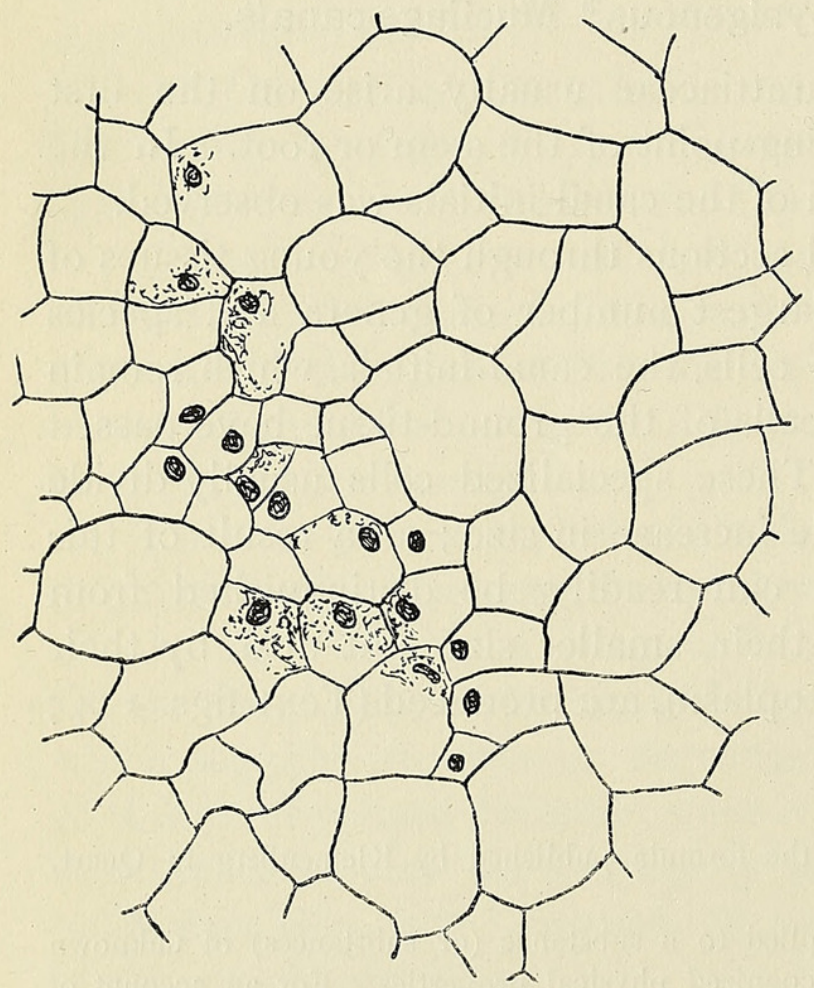

TEXT-FIG. 3. Early stage in development of mucilage-canal in the stem of Marattia fraxinea, Sm. $\times 35^{\circ}$. The shaded areas represent protoplasm in process of mucilaginous degeneration.

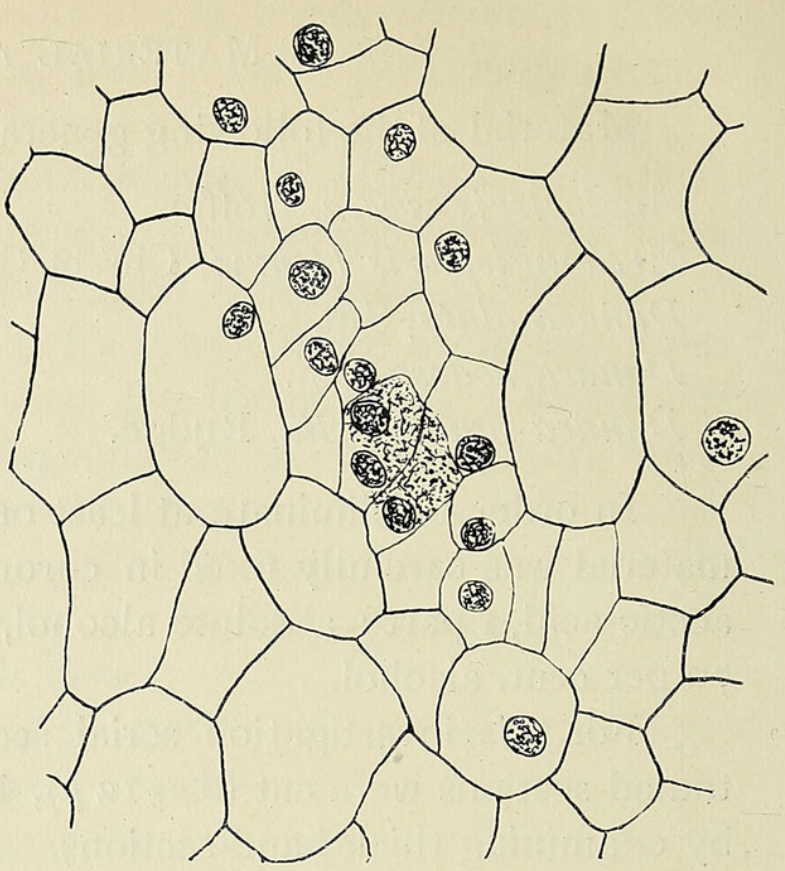

TEXT-FIG. 2. Early stage in development of mucilage-canal in the petiole of Danaea nodosa, Sm. $\times 380$. The shaded areas represent protoplasm in process of mucilaginous degeneration.

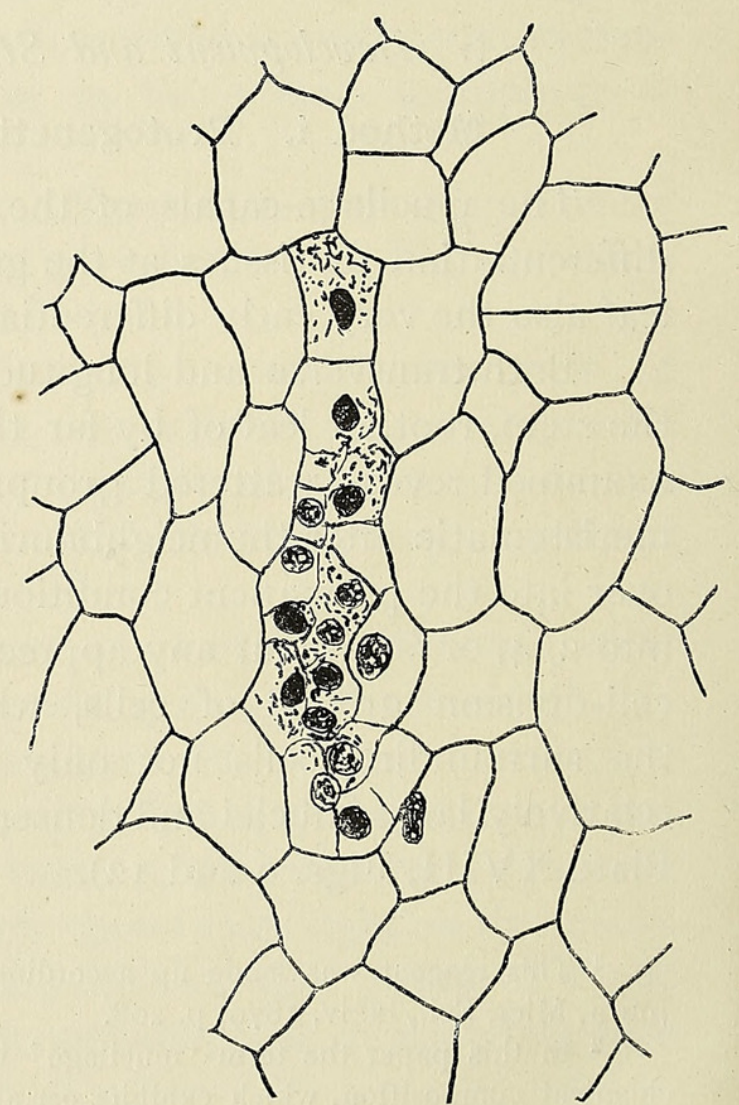

TEXT-FIG. 4. Early stage in development of mucilage-canal in the stem of Kaulfussia aesculifolia, $\mathrm{Bl} . \times 35^{\circ}$. The shaded areas represent protoplasm in process of mucilaginous degeneration. 
The arrangement of the small cells constituting such a group is usually very irregular (Text-figs. 2-4; Figs. 6 and I2).

Most botanists have agreed as to the earlier stages in the development of the mucilage-canals, but much confusion has arisen in the past as a result of the difficulty of correctly interpreting the subsequent stages.

Whereas some (e.g. Frank, Brebner, Lutz) have maintained that the cavity of the duct originates by the splitting apart of the walls of these small cells, which persist as a definite epithelium lining the intercellular space into which they actively secrete mucilage, others (e.g. Kühn, Farmer and Hill, Campbell) have ascribed a lysigenous origin to the canals and have asserted that the cavity is formed by the collapse and disorganization of these groups of cells, which become converted into mucilage.

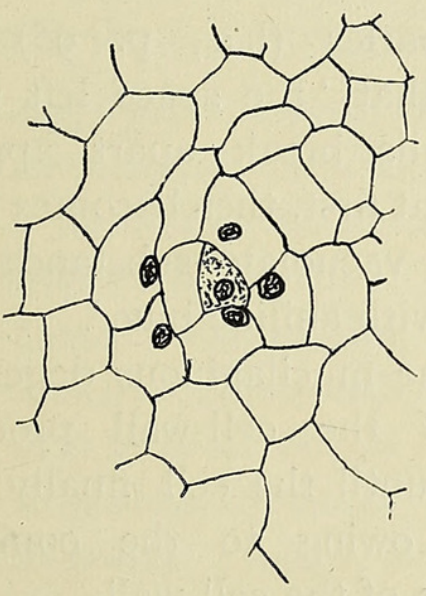

TEXT-FIG. 5 .

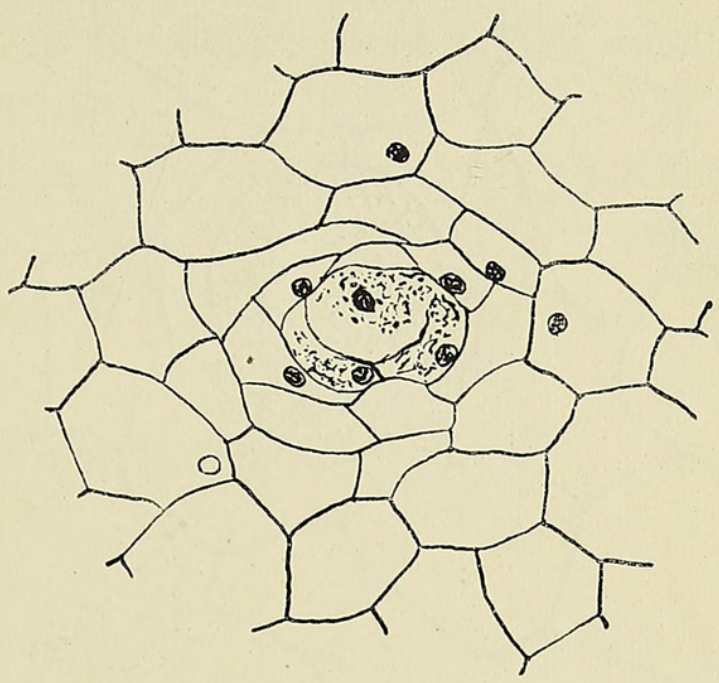

TeXT-Fig. 6.

Early stages in development of mucilage-canals in the stem of Danaea alata, Sm. $\times 35^{\circ}$. The shaded areas represent protoplasm in process of mucilaginous degeneration.

My own observations, which extend over five genera and many species, for the most part confirm the explanation given by the latter group of botanists.

The cytoplasm of certain cells of the group undergoes local mucilaginous degeneration (Text-figs. I-5; Figs. 6 and II-I4). Kleinenberg's haematoxylin was found most satisfactory for demonstrating the changes which take place in the cytoplasm, since it clearly differentiates between the unaltered cytoplasm and that which is undergoing mucilaginous degeneration. This process usually begins near the common point of contact of the cells, and gradually extends through the cytoplasm until finally the entire contents of the cell, including the nucleus, are involved in the change. The cell-contents meanwhile undergo a marked contraction and frequently come away from the cell-wall (Figs. 6 and $\mathrm{I}_{3}$ ).

In this way a condition is attained which might easily be mistaken for a splitting apart of the cell-wall, especially when it is remembered that 
at this stage the cell-wall is also undergoing mucilaginous degeneration and can be seen only with difficulty in thin microtomed sections. However, the cell-wall can still be identified as a very thin line extending across the clear space produced by the contraction of the cytoplasm. It is worthy of note that Brebner (1. c., p. 447) observes that 'in the young developing canals of the frond of Angiopteris evecta, Marattia alata, and Marattia cicutaefolia, there is little or no sign of mucilage, for there does not seem to be anything more highly refractive than the mounting medium in the schizogenous space, nor anything which stains appreciably with safranin or haema-

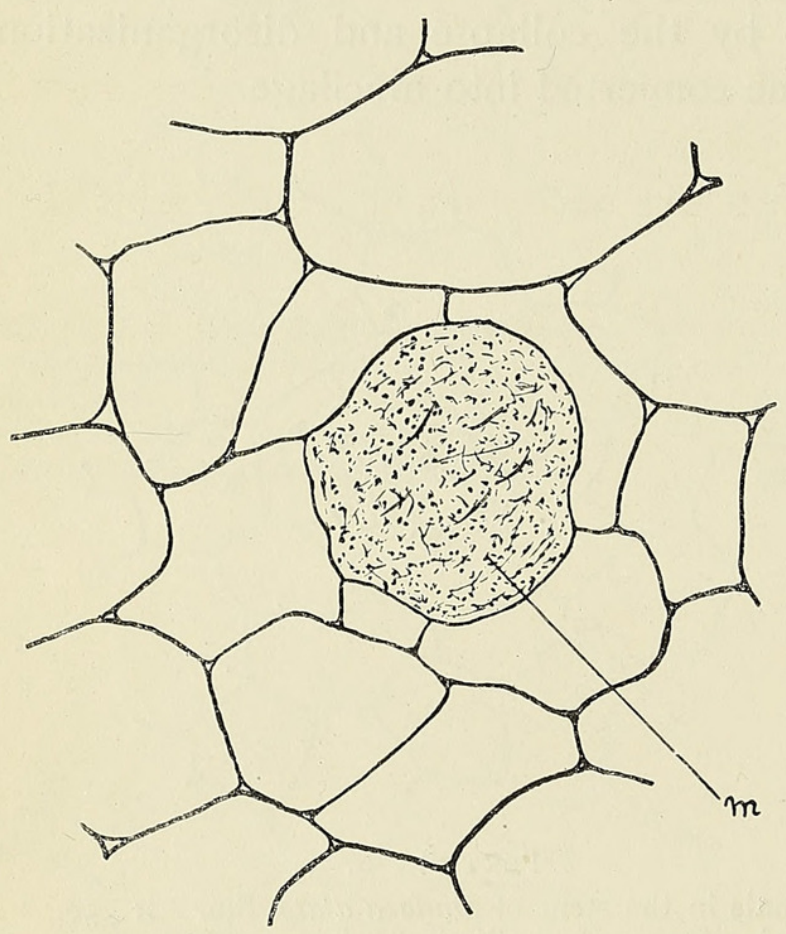

TEXT-FIG. 7. Transverse section of an adult mucilage-canal from the petiole of Archangiopteris Henryi, Chr. et Gies. Note complete absence of epithelial cells. $\times 380 . m_{0}=$ mucilage. toxylin, whereas in the adult condition the cavity is filled with a substance, "mucilage", which stains strongly with these reagents'.

Charles (1.c., p. 96) also states that 'the space left when the walls break apart appears empty at first, then becomes filled with a vacuolate substance that stains with aniline blue'.

The mucilaginous degeneration of the cell-wall proceeds apace until the cell finally collapses owing to the complete solution of the cell-wall.

In this way, then, the cavity of the duct originates (Text-figs. 4 and 6 ; Figs. 6,8 , and $12-14)$.

The rate at which individual cells become disorganized is very unequal; thus, several cells which appear quite healthy may be observed bordering on the duct at a comparatively early stage in its development (Text-fig. 6; Fig. I3, and cf. the 'bridge-cells' of Brebner, 2, p. 446).

Sooner or later, however, they all share the same fate, their disorganized remains contributing to the mucilaginous contents of the duct, which is now surrounded by the unmodified cells of the ground tissue (Text-fig. 7 ; Figs. 7 and 9, m.c.).

Treatment with iodine, as recommended by Brebner (2, p. 447), failed to reveal the presence of an epithelial layer.

The important factor of tissue-tensions, which has been admirably elucidated by G. Kraus (12) and Newcombe (16), appears to have been completely neglected by all previous workers on the development of mucilage-ducts. 
As mentioned above, these elements generally arise just behind the generative tissues of the stem and root and are consequently subjected to a variety of stresses. The stretching of cells due to turgor increases as they pass from the embryonal condition and decreases as they assume their permanent condition, and since the mucilage-ducts in the stem or roots are generally surrounded by parenchymatous cells with thin walls of cellulose, it follows that the latter will tend to contract when the force of turgor is withdrawn. The negative tension thus called forth is considerable, and may account for the very rapid increase in the diameter of the mucilageducts which occur in the stem and roots of most of the genera and species examined (Figs. 8 and I 3 ).

The adult mucilage-ducts, which frequently branch and anastomose, pursue a very irregular course through the ground-tissue.

The above description applies to the development of the mucilageducts in the following genera and species :

Angiopteris evecta, Hoffm. (root excepted) (see also Methods ii and iii). Archangiopteris Henryi, Christ et Gies. (the material of this plant was unsuitable for determining this point with accuracy).

Danaea alata, $\mathrm{Sm}$.

Danaea nodosa, Sm.

Kaulfussia aesculifolia, B1. (see also Method iii).

Marattia alata, Sw.

Marattia attemuata, Lab.

Marattia Cooperi, Mre.

Marattia fraxinea, Sm.

A slight variation from the usual type of development was sometimes observed in the roots of Marattia Cooperi. Here the mucilage-canals may originate from a single row of superposed cells with dense granular cytoplasm. These initial cells do not divide, but rapidly undergo complete mucilaginous degeneration. The nuclei of these cells appear to be remarkably resistant to the enzymes which cause the breaking down of the cells and their contents, and often retain their individuality for a very considerable period after the complete collapse of the cells. They can frequently be found floating in the mucilage.

In this case there can obviously be no doubt as to the true lysigenous origin of the mucilage-ducts (Fig. 10).

\section{Method ii. Protogenetic Schizo-1ysigenous Mucilage-canals.}

In the petiole of Angiopteris evecta an alternative mode of development was noticed for many of the mucilage-ducts. These elements, to which both Brebner (2) and Lutz (14) had attributed a typical schizogenous development, were studied with special care. 
The earliest stages agree in every respect with those described above under Method i, but the later stages follow a somewhat different course. The canal-initials, which arise very early, usually divide into 2, 4, or 6 with no obvious increase in size, and give rise to irregular groups of very small cells with dense cytoplasm and prominent nuclei (Fig. I).

The contents of these small cells immediately begin to show signs of incipient mucilaginous degeneration. This brings about a decrease in the turgidity of the cells, which tend to round themselves off. At the same time small irregular areas are produced between adjacent cells. Special interest attaches to these areas, which are only slightly larger than ordinary intercellular spaces, since they give the staining reactions of mucilage.

It is quite possible, however, that the mucilaginous substance produced at this early stage is derived from the pectin of the middle lamella, which is probably the first part of the cell-wall to become disorganized. Such a condition indicates how typical schizogenous secretory cavities may have arisen. However, the latter are not known to occur in any recent group of Cryptogams.

Strictly speaking, therefore, these mucilage-canals have a schizogenous origin; on the other hand, it is certainly incorrect to say that they have a schizogenous development, since all subsequent increase in size of the cavity (together with the corresponding increase in volume of the mucilage) takes place by the rapid collapse of the surrounding cells.

It often happens that certain of the more peripheral cells of the group divide by walls radial to the centre of the canal; these cells usually retain their normal appearance for a considerable time after the innermost cells have completely lost their individuality. Thus the young mucilage-duct appears to possess a distinct epithelial layer (Figs. 2, 3, and 5).

But these so-called epithelial cells are very irregular in shape and size and have only a transitory existence. Moreover, they do not present the appearances generally associated with a living secretory epithelium.

There is no evidence to show that they have a secretory function; they all very soon break down, their disorganized remains helping to increase the contents of the duct. At a slightly later stage epithelial cells can no longer be detected lining the cavity of the duct, which now abuts directly upon the unmodified parenchymatous cells of the ground-tissue (Fig. 4).

The adult canals are irregularly distributed throughout the parenchyma of the petiole, in which they frequently branch and anastomose (Fig. 5).

\section{Method iii. Hysterogenetic ${ }^{1}$ Lysigenous Mucilage-canals.}

A distinct type of mucilage-duct was found in the adult petiole of Kaulfussia aesculifolia and in large roots of Angiopteris evecta. 
These ducts appear subsequently in old mature tissues and are therefore hysterogenetic. ${ }^{1}$

In the young petiole of Kaulfussia numerous mucilage-ducts, which develop according to Method i, occur, whilst in the young roots of Angiopteris evecta no mucilage-ducts were observed.

This may explain why Van Tieghem (20) failed to find mucilageducts in the roots of this genus. But numerous mucilage-ducts in all stages of development were observed in sections through fairly old petioles of Kaulfussia aesculifolia and through adult roots of Angiopteris evecta. These elements were found in perfectly healthy petioles and roots, and the hypothesis that these canals are formed as the result of traumatic stimuli was proved to be untenable.

They arise by the collapse of groups of typical parenchymatous cells which are in other respects indistinguishable from the other cells which constitute the cortex.

At an early stage these cells can be distinguished by a decrease of turgidity which results in a slight decrease in size, whereby the intercellular spaces, which are typically rather large between the cells of the cortical parenchyma, exhibit a corresponding increase in size. But no signs of mucilage were observed in these intercellular spaces.

Meanwhile the cell-walls rapidly dissolve, while the cell contents become mucilaginous. The cells ultimately break down, and their disorganized remains coalesce to form the stringy mucilaginous contents of the cavity (Figs. 7 and 9).

As Newcombe (1.c.) pointed out, when lysigenous cavities arise subsequently to primary growth, there is generally a collapse but little or no tearing of cells.

The development of these peculiar mucilage-ducts seems to be very irregular both in time and space. The fully developed ducts often exhibit a striking appearance, for they may be very irregular in outline and occasionally attain large dimensions, as is shown in Fig. 9.

\section{Development and Structure of the Tannin-sacs and Tannin-ducts.}

Cells containing tannin are widely distributed throughout the sporophytic tissues of all six genera of the Marattiaceae. ${ }^{2}$

They are generally protogenetic and occur either singly or associated together in groups. When they occur singly they can easily be distinguished by their tanniniferous contents from the neighbouring cells, from which they may or may not differ in shape or size.

Their form varies in different regions of the same organ, but as

1 Frank, 1. c.

2 The present writer's observations on Kaulfussia cannot be reconciled with the statement of Campbell (1.c., p. 185) that in this genus 'tannin-cells are practically entirely absent from the sporophyte throughout its whole existence'. 
a general rule it was noticed that those associated with a vascular bundle are relatively much narrower than those which occur in the ground-tissue.

They invariably possess thin cellulose walls even when they are embedded in the fibrous zone of the petiole (Text-fig. 8).

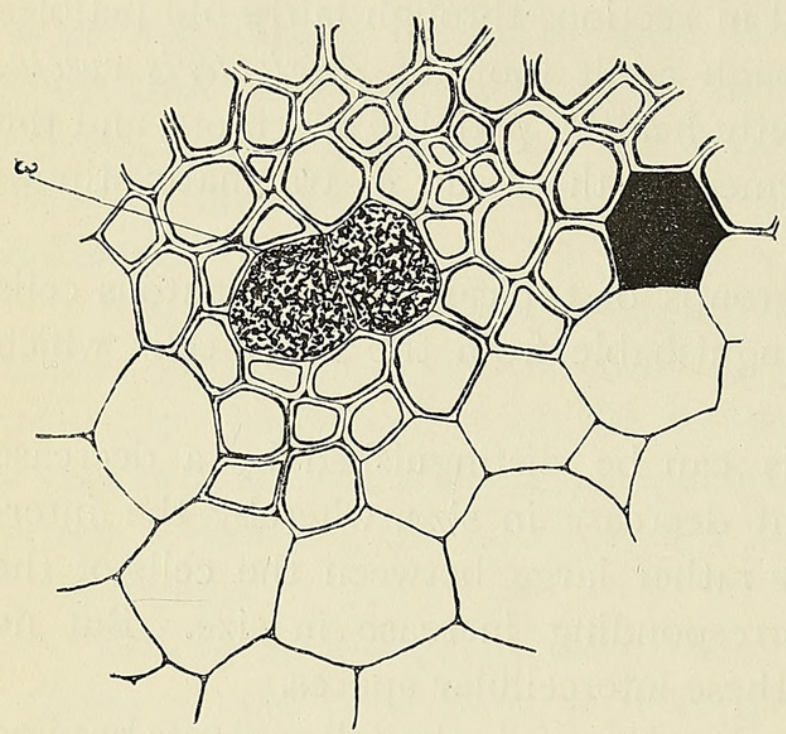

Text-Fig. 8. Tannin-cells in fibrous layer of petiole of Angiopteris evecta, Hoffm. w. = persistent parting-wall. $\times 380$.

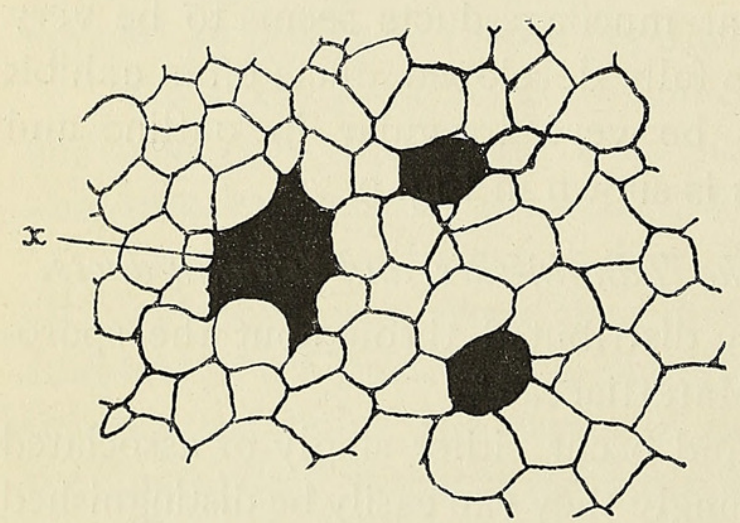

Text-FIG. 9. Tannin-cells in the petiole of Angiopteris evecta, Hoffm. The large tannincell $x$ is crushed by the surrounding parenchyma. $\times 220$.

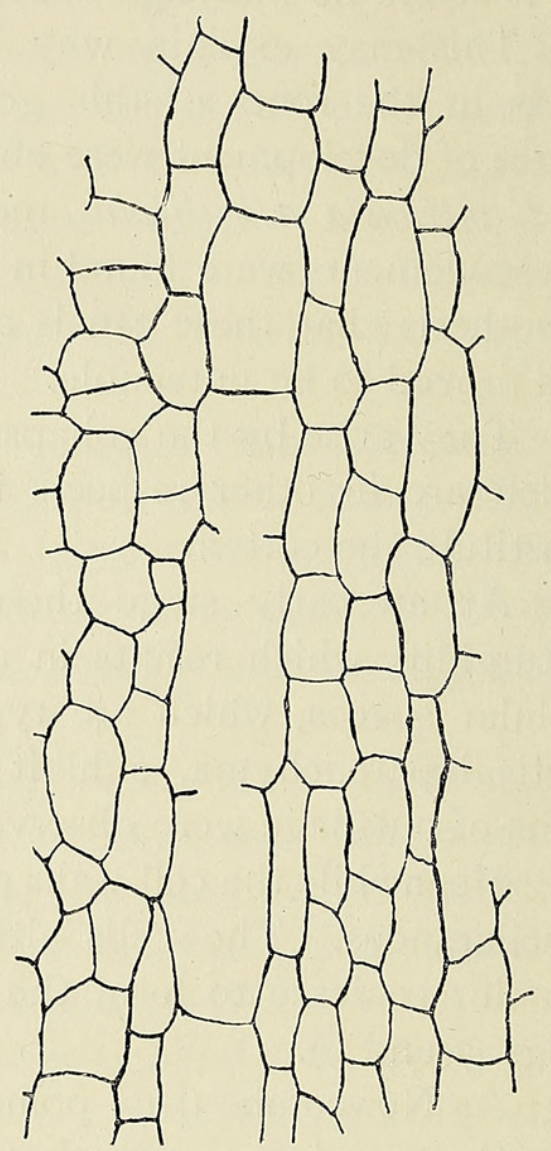

TEXT-FIG. IO. Tannin-duct from the petiole of Angiopteris evecta, Hoffm. The contents of the duct are not shown. $\quad \times 220$.

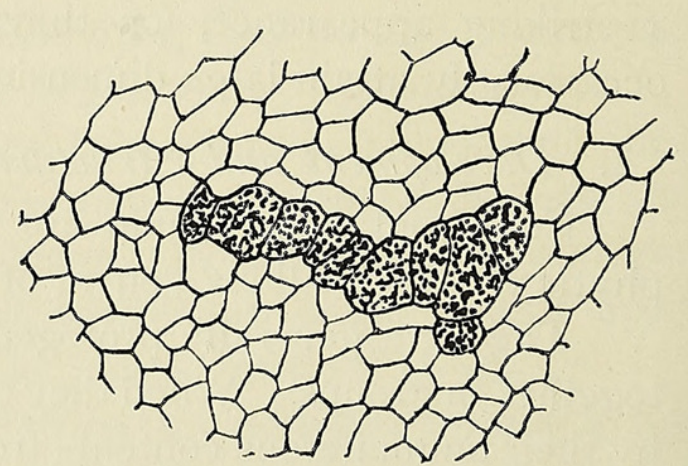

TEXT-FIG. I I. Series of tannin-cells from the stem of Danaea nodosa, Sm. $\times$ I 50 .

They not infrequently occur associated together in regular series of superposed cells, e.g. in the stem, root, and petiole of Angiopteris evecta (Text-fig. IO; Fig. 5, t.c.); in the root of Danaea alata, Danaea nodosa, and 
Marattia attenuata; and in the petiole of Danaea simplicifolia, Marattia alata, \&c., \&c.

They are less frequently associated together in irregular groups, e.g. in the stem of Danaea nodosa (Text-fig. II), and in the sporangium wall of Kaulfussia aesculifolia, \&c., \&c.

It sometimes happens that the parting-walls of adjacent tannin-cells break down, the solution of the wall beginning in the centre and gradually spreading until a typical vessel or duct is formed, e. g. in the petiole and root of Angiopteris evecta (Text-fig. Io, and cf. Farmer, 1. c., p. 269 and Pl. XV, Fig. I2), and in the root of Marattia attemata. The breaking down of the parting-walls bears no relation to the age of the cells; it may take place either in very young or in fairly old tissues.

Such a series of stages in the development of a typical tannin-duct was described and illustrated by Lutz (1. c., pp. I34, I35; P1. II, Figs. 3-7), who, however, mistook these tannin-ducts for lysigenous mucilage-canals, and stated that the tannin was eventually replaced by mucilage.

I was quite unable to confirm this explanation, since in all my material the tannin-cells (or ducts) are from the very beginning absolutely distinct, and, even in old specimens, bear no resemblance to the mucilage-canals. Whereas the mucilage-canals freely branch and anastomose (Fig. 5), the tannin-ducts seldom branch and never anastomose.

From our knowledge of the chemical composition of these secretions it would appear very improbable that one should be converted into the other; notwithstanding that in certain Angiosperms tannin occurs associated with mucilage.

In the stem of Danaea nodosa and in the sporangium wall of Kaulfussia aesculifolia irregular tannin-containing cavities are produced by the breaking down of the parting-walls between adjacent tannin-cells.

A true secretory epithelium is never present round the tannin-cells or tannin-ducts, but their contents often exert a considerable pressure upon the surrounding cells, which are slightly crushed and assume the appearance of an epithelium, to which, however, they bear only a superficial resemblance.

On the other hand, the tannin-cells (or ducts) are often compressed by the surrounding parenchyma (Text-fig. 9 ; Figs. 4 and 5).

Tannin-sacs are abundant in the ramenta of Angiopteris evecta, Danaea nodosa, Danaea alata (Text-figs. I2 and I3), Marattia Cooperi, and Marattia fraxinea; in the characteristic two-celled hairs of the petiole of Kaulfussia aesculifolia (Text-fig. I4); and in the paleae of Archangiopteris Henryi.

Wound-tannin. A copious secretion of tannin was observed in the immediate neighbourhood of wounds. In this respect the tannin may be compared with the secretion of resin which is induced by traumatic stimuli in certain Conifers.

Theoretical considerations. In all the genera of Marattiaceae examined 
by the present writer typical lysigenous mucilage-ducts were found. But in the petiole of Angiopteris evecta an alternative schizo-lysigenous development of the mucilage-ducts was observed. The cells lining the cavity of these ducts develop as an indefinite transitory epithelium. Thus it seems that, as Farmer and Hill (1.c., pp. 390-I) previously pointed out, the primitive method of mucilage-duct formation in this group of Ferns is

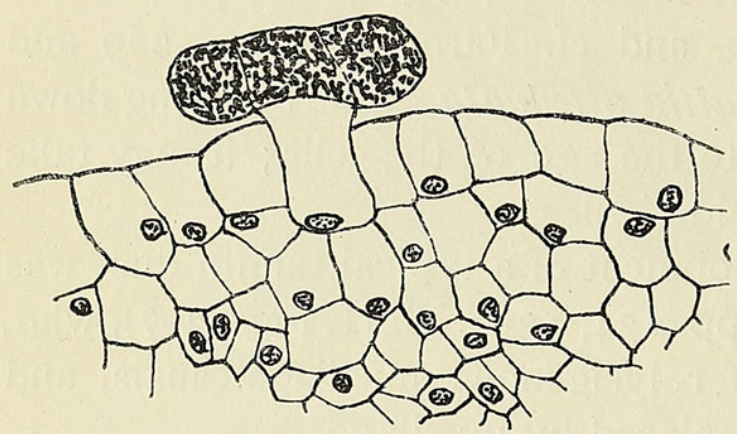

TEXT-FIG. I 2.

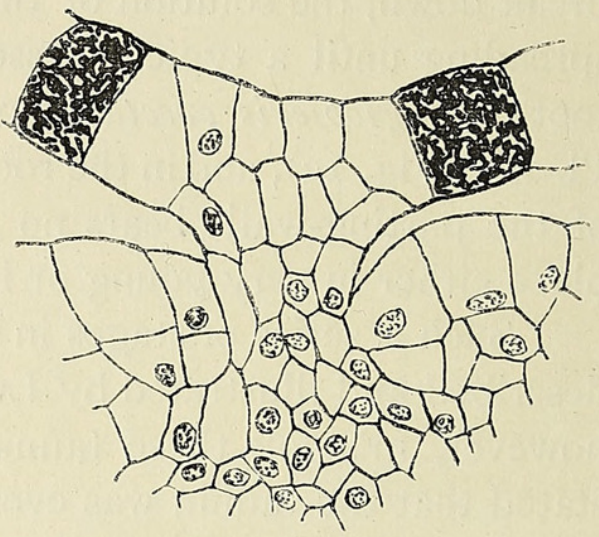

TEXT-FIG. I3.

Tannin-cells in ramenta of Danaea alata, Sm. $\times 280$.

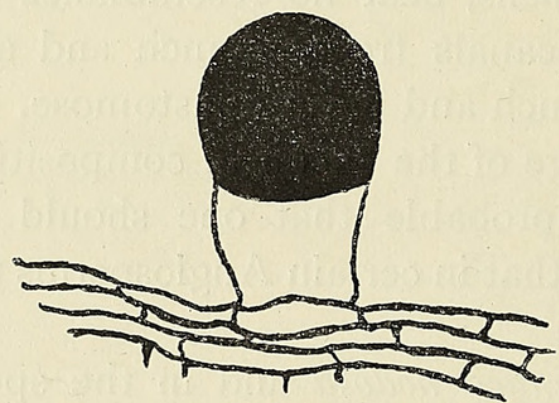

Text-FIg. I4. Tannin-cell in hair on petiole of Kanlfussia aesculifolia, Bl. $\times 280$.

lysigenous. The more advanced schizo-lysigenous method is restricted to the petiole of Angiopteris evecta.

It is generally acknowledged that this genus is the most specialized member of the Marattiaceae, and hence it is not surprising that in this genus alone a more complex mode of mucilage-duct formation obtains.

The form and position of the tannin-cells and tannin-ducts vary considerably even in different individuals of the same species, and afford no means of generic or specific distinction.

Functions of the secretions. Although the mucilaginous secretions are produced in the youngest parts of the plants, they do not disappear from the older parts, and consequently are lost to the plant when the leaves and their appendages are thrown off or when the stem and roots decay away.

It would thus appear that the mucilage constitutes a waste-product of the plant. The same explanation will serve for the tannin-sacs (and ducts), which also persist throughout the life of the plant organ in which they occur. 
Both types of secretory tissue are equally abundant in the stem, leaves, and roots of these Ferns; it is therefore improbable that they are produced in connexion with a water-storing function, especially when it is remembered that all the representatives of this family are usually confined to localities where they would not be subjected to long periods of drought.

Whether these substances possess any biological significance in connexion with the attacks of animals or of parasitic Fungi it is impossible to say.

\section{SUMMARY.}

I. Lysigenous mucilage-canals were found in every genus and species of Marattiaceae examined. They are usually protogenetic, but occasionally hysterogenetic (e.g. petiole of Kaulfussia aesculifolia; root of Angiopteris evecta).

In the petiole of Angiopteris evecta the mucilage-canals may be lysigenous or schizo-lysigenous.

2. Tannin-cells are widely distributed through the sporophytic tissues of the Marattiaceae ; they occur either as isolated tannin-sacs or grouped together in regular or irregular series.

Lysigenous tannin-ducts are formed by the solution of the septa between adjacent tannin-cells.

In conclusion, I desire to express my thanks to Professor J. B. Farmer, F.R.S., for much helpful advice and criticism.

\section{LITERATURE CITED.}

1. Bitter, G.: 'Marattiaceae' in Engler and Prantl, Die natürlichen Pflanzenfamilien, I. Th., 4. Abt., 1900.

2. Brebner, G.: On the Mucilage-canals of the Marattiaceae. Journ. Linn. Soc. (London), Bot., vol. $\mathrm{xxx}, \mathrm{I} 895$.

3. On the Anatomy of Danaea and other Marattiaceae. Ann. of Bot., vol. xvi, I902.

4. Campbell, D. H.: The Eusporangiatae. Publication No. $\mathrm{I}_{4} \mathrm{O}$ of the Carnegie Institute. Washington, I9II.

5. Bot., vol. xxviii, I9I4.

6. Charles, G. M.: The Anatomy of the Sporeling of Marattia alata. Bot. Gaz., vol. li, I9I I.

7. De Vriese, W. H., et Harting, P. : Monographie des Marattiacées, i8 53.

8. Farmer, J. B.: The Embryogeny of Angiopteris evecta, Hoffm. Ann. of Bot., vol. vi, I892.

9. Angiopteris evecta and some other Marattiaceae. Ann. of Bot., vol. xvi, I902.

10. Frank, A. B. : Beiträge zur Pflanzenphysiologie. Leipzig, I868.

11. Karsten, H. : Vegetationsorgane der Palmen. Schriften d. königl. Akad. d. Wiss., Berlin, I 847.

12. Kraus, G. : Die Gewebespannung des Stammes und ihre Folgen. Bot. Zeit., Bd. xxv, I867.

13. KüHN, R. : Untersuchungen über die Anatomie der Marattiaceen. Flora, Bd. lxxii, I889. 
14. Lutz, M. L.: Sur l'origine des canaux gommifères des Marattiacées. Journ. de Botanique, t. xii, 1898 .

15. Matte, H. : Recherches sur l'appareil libéro-ligneux des Cycadacées. Caen, I904.

16. Newcombe, F. C.: The Cause and Conditions of Lysigenous Cavity-Formation. Ann. of Bot., vol. viii, 1894 .

17. Rudolph, R.: Psaronien und Marattiaceen, vergleichend-anatomische Untersuchung. Denkschr. math.-naturw. Kl. d. kais. Akad. d. Wiss., Bd. lxxviii. Wien, I905.

18. Russow, E.: Vergleichende Untersuchungen, etc. Mém. de l'Acad. Imp. des Sciences de Saint-Pétersbourg, sér. 7 , vol. xix, 1872 .

19. Seward, A. C.: On Rachiopteris Williamsonii, sp. nov., a new Fern from the Coal Measures. Ann. of Bot., vol. viii, I894.

20. Tieghem, Ph. van : Recherches sur la symétrie de structure des plantes vasculaires. Ann. Sc. Nat. (Bot.), $5^{\text {e }}$ sér., t. xiii, 1870.

21. Trécul, A.: Des vaisseaux propres et du tannin dans quelques fougères. Ann. Sc. Nat. (Bot.), 5 ér., t. xii, 1869 .

22. Tschirch, A.: Angewandte Pflanzenanatomie, I 889.

\title{
EXPLANATION OF PLATE XVIII.
}

\author{
Illustrating Mr. West's paper on the Structure and Development of the Secretory \\ Tissues of the Marattiaceae.
}

Figs. I, 2, and 3. Successive stages in the development of mucilage-canals. In Fig. 3 the transitory epithelium is shown. From longitudinal sections of a young petiole of Angiopieris evecta, Hoffm. $\times 280$.

Fig. 4. Part of a transverse section of an older petiole of Angiopteris evecta, Hoffm., showing four adult mucilage-canals in transverse section. Note complete absence of epithelial cells. t.c. $=$ tannin cells. $\times$ roo.

Fig. 5. Part of a longitudinal section of a young petiole of Angiopteris evecta, Hoffm., showing early stage in development of a mucilage-canal. $\quad$ t.c. $=$ tannin cells. $\times 60$.

Fig. 6. Early stage in the development of a mucilage-canal. The protoplasm of many of the small cells is undergoing mucilaginous degeneration; at $x$ the cell-walls have disappeared. From a transverse section of a young petiole of Danaea nodosa, Sm. $\quad \times 280$.

Fig. 7. Part of a transverse section of an old root of Angiopteris evecta, Hoffm., showing early stage in the formation of a mucilage-canal by the mucilaginous degeneration of part of the cortical parenchyma. $m_{0}=$ mucilage. $\times 280$.

Fig. 8. Part of a longitudinal section through the apical region of a large root of Marattia Cooperi, Mre., showing a young mucilage-canal. Note absence of epithelial cells. $m_{\bullet}=$ mucilage; $n .=$ nuclei of disorganized cells floating in the mucilage. $\times$ roo.

Fig. 9. Part of a transverse section of an adult petiole of Kaulfussia aesculifolia, B1., showing a large irregular mucilage-canal formed by the mucilaginous degeneration of typical parenchymatous cells of the ground-tissue. m.c. $=$ mucilage-canal of the usual type. $\times 100$.

Fig. Io. Early stage in the development of a mucilage-canal from a single row of canal-initials. From a longitudinal section through the apical region of a large root of Marattia Cooperi, Mre. $\times$ I00.

Fig. II. Part of a transverse section of a large root of Danaea alata, Sm., showing early stages in the development of mucilage-canals. $\quad$ t.c. $=$ tannin-cell. $\times$ Ioo.

Fig. I2. Early stage in the development of a mucilage-canal. The protoplasm of many of the small cells has undergone mucilaginous degeneration, while several of the cell-walls have already disappeared. From a transverse section of a young petiole of Marattia Cooperi, Mre. $\quad \times 280$.

Fig. I3. Part of a longitudinal section through the apical region of a large root of Danaea nodosa, Sm., showing early stage in the development of a mucilage-canal. $\times 280$.

Fig. I4. Early stage in the development of a mucilage-canal. The protoplasm of several of the small cells has undergone mucilaginous degeneration; at $x$ the cell-walls have completely disappeared. From a longitudinal section of a young petiole of Kaulfussia aesculifolia, Bl. $\times 280$. 

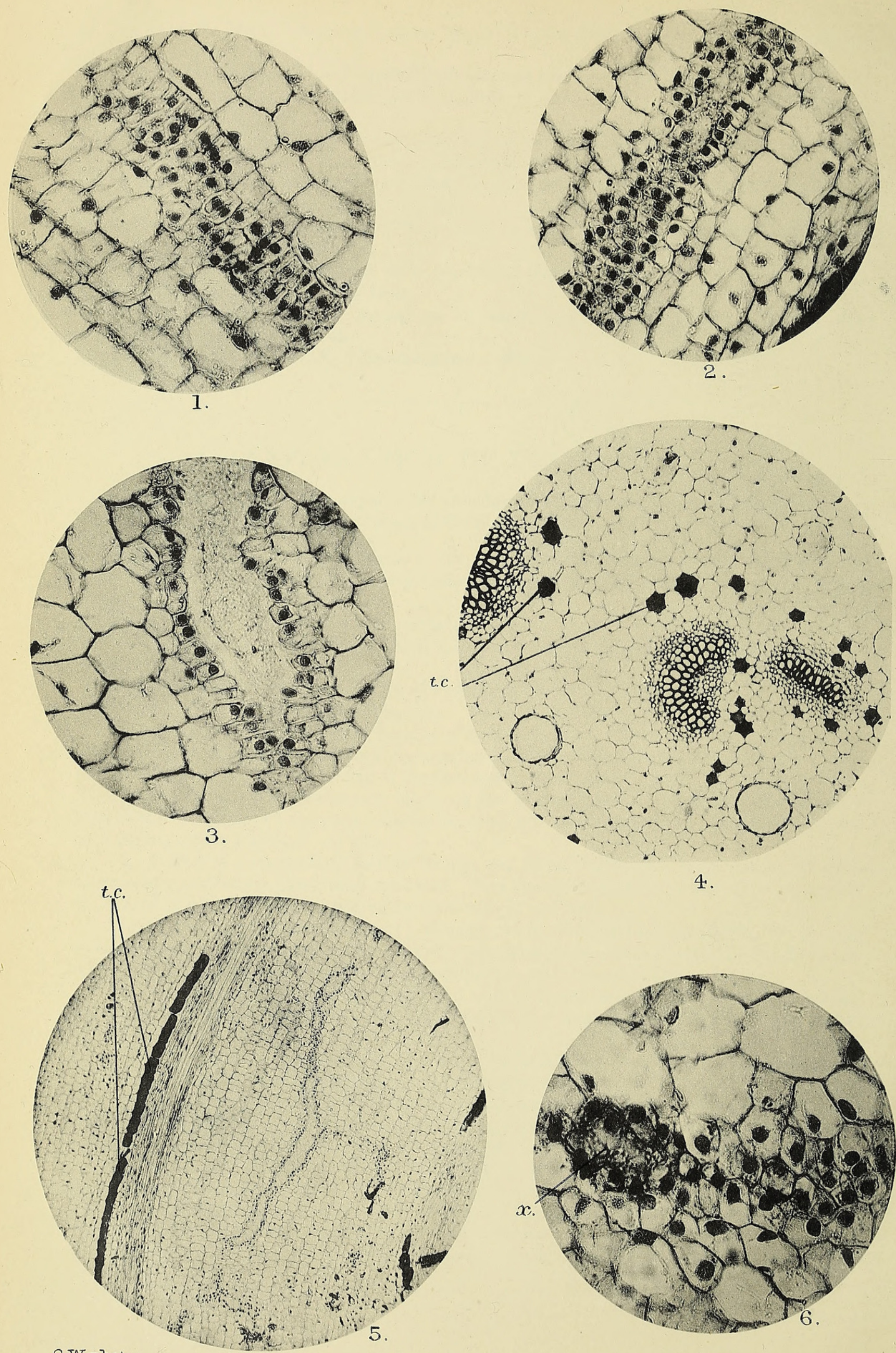

4.

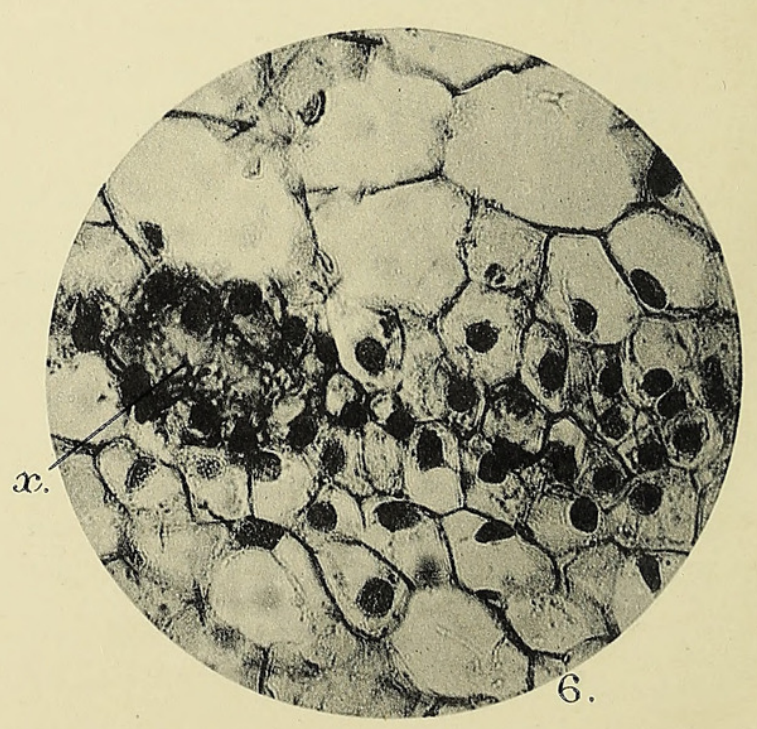

C.W. phot. 
Vol. XXIX. Pl XVIII.
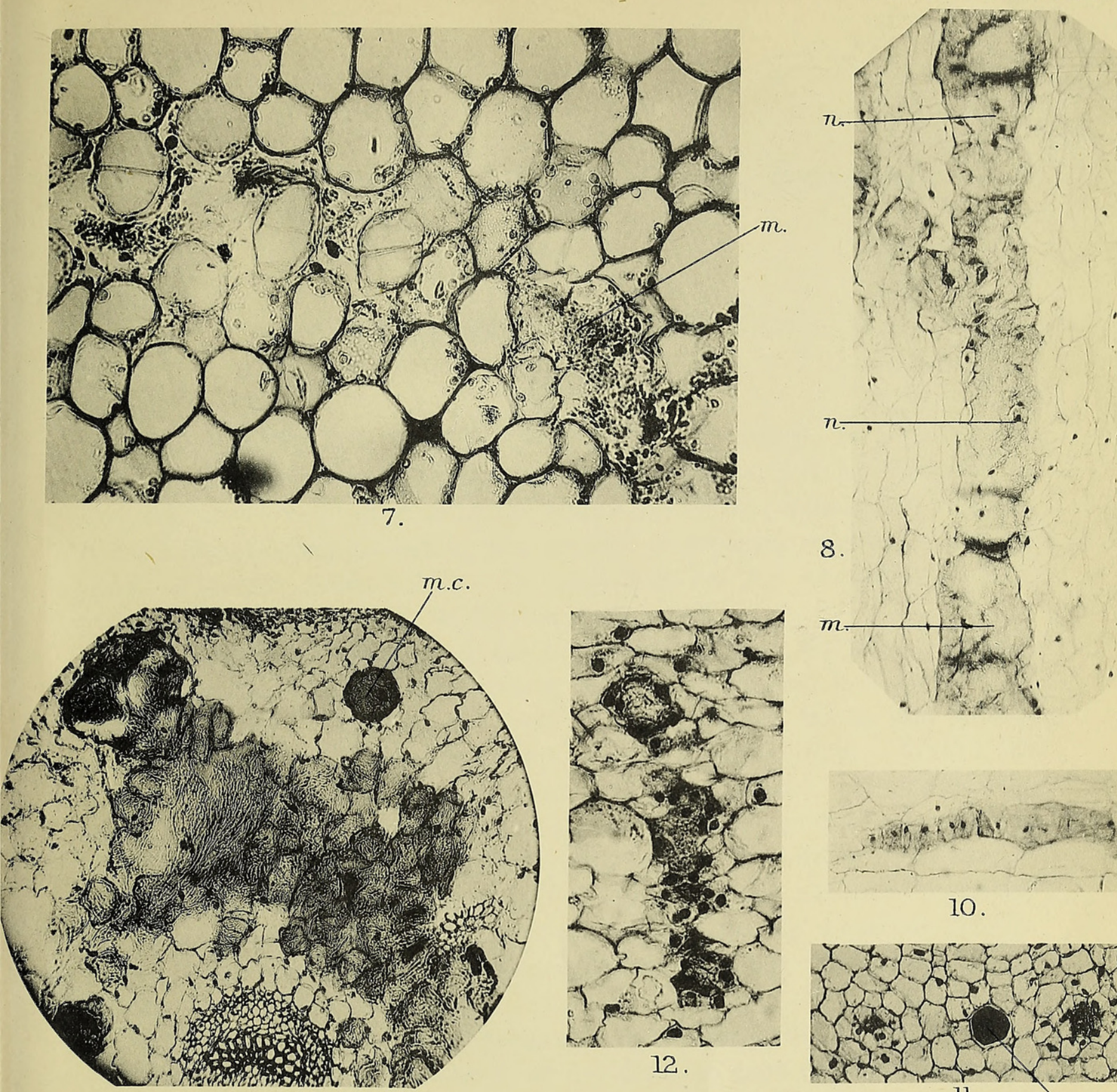

9.
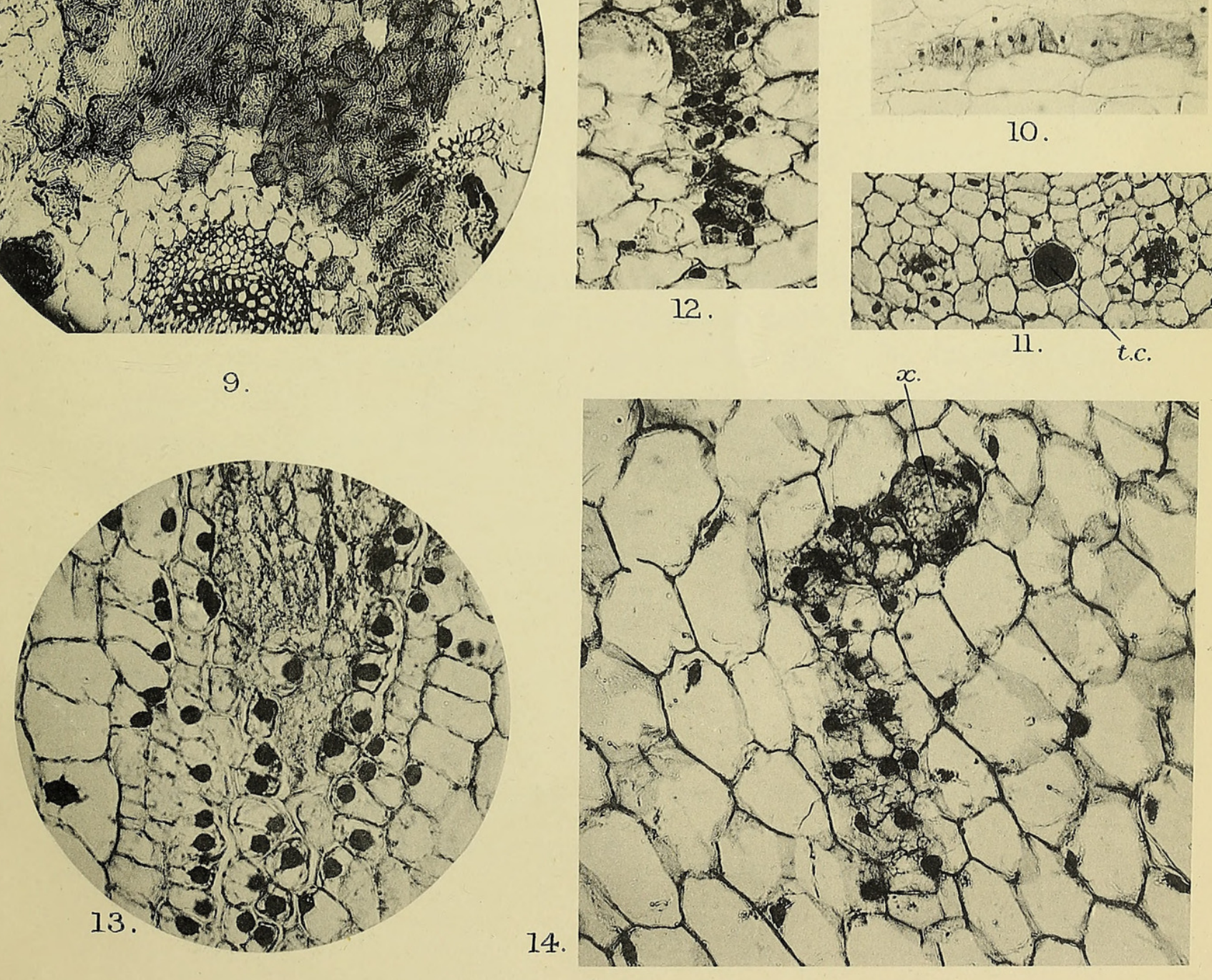

10.

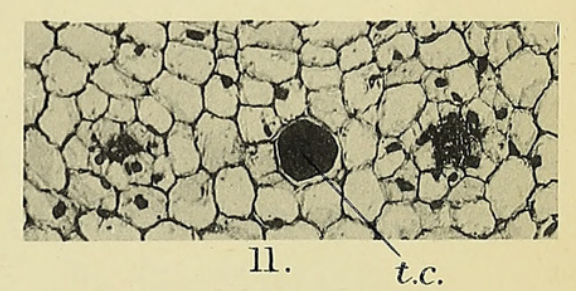




\section{$2 \mathrm{BHL}$ Biodiversity Heritage Library}

West, Cyril. 1915. "On the structure and development of the secretory tissues of the Marattiaceae." Annals of botany 29, 409-422. https://doi.org/10.1093/oxfordjournals.aob.a089555.

View This Item Online: https://www.biodiversitylibrary.org/item/243629

DOI: https://doi.org/10.1093/oxfordjournals.aob.a089555

Permalink: https://www.biodiversitylibrary.org/partpdf/320072

\section{Holding Institution}

Smithsonian Libraries

\section{Sponsored by}

Biodiversity Heritage Library

\section{Copyright \& Reuse}

Copyright Status: Not in copyright. The BHL knows of no copyright restrictions on this item.

This document was created from content at the Biodiversity Heritage Library, the world's largest open access digital library for biodiversity literature and archives. Visit BHL at https://www.biodiversitylibrary.org. 